\title{
ANALISIS KETAMPANAN NABI YUSUF DALAM PERSPEKTIF SEMIOTIKA AL-QUR'AN*
}

\author{
Muhammad Akrom \\ Prodi Linguistik Fakultas IImu Pengetahuan Budaya Universitas Indonesia \\ email : akrom3muhammad@gmail.com
}

\begin{abstract}
The topic of this research is the Qur'an semiotics on surah Yusuf. This research collaborates the theory of semiotics and al-Qur'an. This research aims to find out the sense, meaning, and messege of the Qur'an on surah Yusuf. The theories used in this research are theory of meaning component, theory of sense relation, and theory of semiotics. This research is used two approaches. First, heuristic or semantics and second, retroactive or semiotics.
\end{abstract}

Keywords: sense, meaning, semiotic, and al-Qur'an

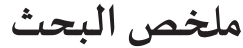

جمالية يوسف عليه السام التي أشـار إليها القرآن سوف تكون بليغة إذا انتهجت دراستها دراسـة تحليلية باتباع المنهج السيميائي. وبناء على نظريـة الحقل الدلالي، ونظرية علاقة المعنى، ونظريـة السيميائية، تقدم هذه المقالة تحليلا استكشافيا ثريا بالمعنى وقاطع الدلالة. بدءا من افتراض مرسل الرسالة (الله)، تقدم مجموعاءة

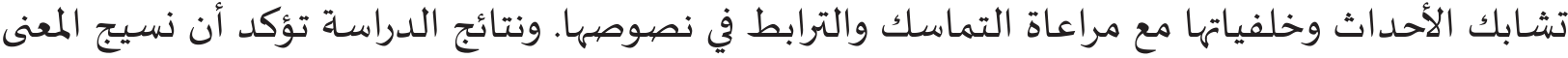
المقصيود من قبل مرسل الرسالة هو أن لجمالية يوسف في القرآن شخصية مثالية ينبغي للمسلم أن يطبقها في حياة الإيمانية.

النقاط الحاكمةة: القرآن، جمالية يوسف، مدخل السيميائية، نظريات المعنى، الحقل الدلالي، تحليل النص

\begin{abstract}
Abstrak
Ketampanan Nabi Yusuf yang diisyaratkan oleh al-Qur'an apabila ditelaah dengan menggunakan pendekatan semiotik akan menghasilkan pesan yang lebih utuh. Mengacu teori medan makna, teori hubungan makna, dan teori semiotik, tulisan ini menghadirkan sebuah analisis heuristik dan semiotik yang padat nilai dan bernas. Diawali dengan presuposisi yang dimaksud pengirim pesan (Allah), penulis lalu menghadirkan jalinan peristiwa secara naratif beserta latarnya dengan tetap memperhatikan kohesi dan koherensi teks. Temuan kajian ini menegaskan bahwa jalinan makna yang dimaksud oleh pengirim pesan tentang ketampanan Nabi Yusuf adalah idealitas kepribadian yang layak dicontoh oleh insan bertakwa.
\end{abstract}

Kata Kunci: ketampanan Yusuf, al-Qur'an, pendekatan semiotik, analisis teks, kohesi, koherensi 


\section{Pendahuluan}

Dengan menggunakan bahasa Arab sebagai media ekspresi pesan-pesan Tuhan kepada manusia, eksistensi al-Qur'an tidak dimungkiri telah menjadi lahan subur bagi kajian semiotika. Semiotika adalahcabang ilmu yang mengkaji tentang tanda-tanda. Ilmu ini menganggap bahwa fenomena sosial dan kebudayaan merupakan sekumpulan tanda-tanda.Secara garis besar, ranah kajian semiotika dibagi menjadi dua, semiotika signifikasi yang digerakkan oleh Ferdinand de Saussure (1857-913) dan semiotika komunikasi yang diinspirasi oleh Charles Sanders Pierce (1839-1914).

Semiotika signifikasi ditekankan pada aspek hubungan antara penanda dan petanda, sedangkan semiotika komunikasi ditekankan pada aspek komunikasi. Semiotika mengkaji sistem-sistem dan aturan-aturan atau konvensi-konvensi yang memungkinkan suatu tanda dalam masyarakat memiliki arti. Sistem tanda yang menjadi hasil konvensi masyarakat ini sangat luas seiring dengan pembentukan dan perkembangan pranata sosial dan budayanya, sehingga semiotika pun memiliki ranah kajian yang begitu luas.

Semiotika al-Qur'an dapat didefinisikan sebagai cabang ilmu semiotika yang mengkaji tanda-tanda dalam al-Qur'an, antara lain seperti: kalimat, kata atau huruf, dan totalitas struktur di dalamnya. ${ }^{1}$ Dalam konteks ini, Arkoun (1994) mendasarkan sebuah hipotesis sebagai berikut: "alQur'an mengandung sejumlah pemaknaan potensial yang diusulkan kepada semua manusia. Pada tahap pemaknaan ini, alQur'an mengacu pada agama transejarah yang tahap pemaknaannya diaktualisasikan dalam doktrin teologis, yuridis,

\footnotetext{
1 Ali Imron, Semiotika Al-Qur'an (Yogyakarta: Teras, 2011), cet. 1, h. 5 .
}

filsafat, politis, etis, dan sebagainya yang kurang lebih telah dirasuki oleh makna transendensi."

Tulisan ini merupakan hasilpenelitian yang berusaha menjawab rumusan masalah: "Bagaimana semiotika digunakan dalam menganalisis dan mengungkap makna atau pesan yang terkandung di dalam al-Qur'an?" Penelitian ini bertujuan untuk mengungkap makna atau pesan alQur'an dengan menggunakan pendekatan semiotika. Mengingat bahwa penggunaan semiotika dalam kajian al-Qur'an dapat berubah menjadi "penafsiran", penulis perlu tegaskan bahwa temuan dari kajian ini bukanlah penafsiran. Sebab, penggunaan semiotika di sini bukan dimaksudkan sebagai sebuah metode penafsiran al-Qur'an melainkan hanya sekadar pendekatan untuk memperoleh pemahaman.

\section{Metodologi Penelitian}

Penelitian ini menggunakan pendekatan kualitatif karena data yang dianalisis berupa teks yang membutuhkan pemaknaan dan penafsiran mendalam. Menurut Creswell, penelitian kualitatif adalah proses penelitian untuk menyelidiki dan memahami suatu fenomena individu atau kelompok yang dianggap berasal dari masalah sosial dan kemanusiaan. Pada pendekatan ini, seorang peneliti membuat suatu deskripsi yang kompleks, meneliti kata-kata, laporan terinci, dan melakukan studi pada situasi yang alami. ${ }^{3}$ Pendekatan kualitatif digunakan dalam penelitian ini untuk menjawab pertanyaan dalam rumusan masalah, yaitu menemukan,

2 Mohammed Arkoun, Nalar Islami dan Nalar Modern: Berbagai Tantangan dan Jalan Baru (Jakarta: INIS, 1994), cet. 1.

3 John W Cresswell, Research Design: Qualitative Quantitative, and Mixed Methods Approaches, Third Edition (USA: Sage Publication, Inc. 2009), h. 4. 
mengungkap, serta membuat penjelasan secara mendalam atas fenomena yang dijadikan objek dalam kajian ini.

Data dalam penelitian ini adalah teks al-Qur'an. Pemilihan teks al-Qur'an sebagai sumber data penelitian didasarkan pada alasan bahwa al-Qur'an secara linguistik adalah sebuah korpus yang selesai dan tertutup bagi ujaran-ujarandalam bahasa Arab (tidak dapat direproduksi), sedangkan kita tidak lagi memiliki jalan masuk kepadanya kecuali melalui teks. ${ }^{4}$ Adapun teks al-Qur'an yang digunakan sebagai data dalam penelitian ini merupakan jenis bahasa ragam tulis.

Data penelitian ini dikumpulkan dan diseleksi dari ayat-ayat al-Qur'an, lalu analisisnya diambil dari sampel secara acak melalui teknik random atau probability sampling. Secara spesifik, teknik yang penulis gunakan adalah pengambilan sampel acak sederhana.Pemerolehan data penelitian ini dilakukan melalui dua tahap. Pertama, menemukan kata, kosakata, kalimat,dan ayat dalam al-Qur'an. Kedua, mengamati keutuhan makna dan kandungan ayat dalam satu topik dengan meninjau aspek kohesi dan koherensi wacananya. Kedua tahap ini digunakan agar data yang terjaring memiliki keakuratan sesuai dengan tujuan penelitian yang telah dirumuskan.

Data yang terhimpun kemudian dianalisis. Analisis data menggunakan dua pendekatan. Pertama, pendekatan semantik, yakni pembacaan terhadap ayatayat al-Qur'andengan menggunakan ilmu semantik (heuristik). Kedua, pendekatan semiotik, yakni pembacaan terhadap alQur'andengan menggunakan ilmu semiotik (retroaktif).

\footnotetext{
$4 \quad$ Mohammed Arkoun, op. cit, h. 91.
}

\section{Teori Makna dan Studi Makna}

Dalam studi makna, Nida menjelaskan dua macam pendekatan, yaitu pendekatan ekstensional dan pendekatan intensional. Pendekatan ekstensional dititikberatkan pada bagaimana satuan leksikal dipakai dalam konteks, baik konteks linguistik maupun komunikasi. Pendekatan intensional lebih berfokus pada struktur-struktur konseptual yang diasosiasikan dengan unitunit leksikal tertentu serta memprediksi bagaimana unit tersebut dapat digunakan untuk menentukan referentertentu lainnya. Pendekatan intensional tidak bisa hanya mengandalkan intuisi peneliti, tetapi harus menggunakan prosedur komparasi. ${ }^{5}$

Cruse juga menyebutkan dua macam konsep pendekatan. Pertama, pendekatan ekstensional, yaitu pendekatan yang berusaha mengkorelasikan ekspresiekspresi bahasa dengan segala aspek realitas di dunia.Misalnya, kalimat kucing itu lapar. Secara denotatif, kata kucing merujuk pada seekor binatang yang dikenal oleh manusia dengan kucing, sedangkan frasakucing itu merujuk pada 'kucing' tertentu yang dimaksudkan oleh penutur. Kedua, pendekatan intensional, yaitu pendekatan yang menekankan pada maksud tertentu yang direpresentasikan oleh pengujarnya. Dalam contoh kalimat di atas, kata kucing tidak dihubungkan dengan benda atau binatang 'kucing' yang dikenal manusiatetapi sebuah representasi mental manusia tentang apa yang disebut 'kucing'. Representasi semacam ini disebut makna kata (sense of the word). ${ }^{6}$ Apabila dua model pembacaan di atas diterapkan di dalam

5 Eugene A.Nida, Componential Analysis of Meaning: An Introduction of Semantic Structure (The Hague: The Netherlands Mouton\& Co. NV. Publisher, 1975), h. 22-25.

6 D. Alan Cruse, Meaning in Language: An Introduction to Semantics andPragmatics (Oxford: Oxford University Press, 2004), h. 24. 
pengkajian ayat al-Qur'an, maka model pembacaan seperti itu disebut pembacaan secara semantik.

Lyons (1977, 1995) membedakan reference (pengacuan), denotation (denotasi), sense (pengertian), dan naming (penamaan). Menurutnya, perbedaan antara reference dengan denotation terletak pada objek yang terkait dengan suatu satuan bahasa. Lyons menambahkan bahwa reference dari suatu ungkapan berkaitan dengan suatu objek yang jenisnya berbedabeda dan tidak terlepas dari apa yang dimaksudkan oleh tuturan, sedangkan denotation memiliki kaitan dengan objek dan tidak terikat dengan tuturan. ${ }^{7}$ Sense adalah relasi antara kata, satuan leksikal, atau ungkapandengan referen. ${ }^{8}$ Sense juga merupakan himpunan relasi makna dalam suatu bahasa. ${ }^{9}$ Sementara itu, naming merupakan fungsi semantis yang paling mendasar dari satuan leksikal. ${ }^{10}$

Lyons memahami sense sebagai meaning yang merujuk pada makna atau deskripsi dalam kognisi manusia. Sementara itu, Cruse (2004) berpendapat bahwa fungsi bahasa adalah untuk memindahkan yang ada dalam kognisi manusia. Konsep-konsep reference (pengacuan), denotation (denotasi), dan naming (penamaan) selanjutnya disebut komponen utama dari sense(pengertian) yang akan membatasi referen (reference). Dengan kata lain, dalam pandangan Cruse,sense sejajar dengan konsep; dan apa yang disampaikan Lyons dan Cruse itu pada dasarnya sama. Karena itu, istilah sense (pengertian) dan meaning (makna) dalam

\footnotetext{
7 Jhon Lyons, Linguistic Semantics: An Introduction, (Cambridge: Cambridge University Press, 1995), h. 79.

8 Jhon Lyons, Semantic (Cambridge: Cambridge University Press, 1977), h. 206.

9 Jhon Lyons, Linguistic Semantics: An Introduction, h. 80.

10 Eugene A Nida, op. cit., h. 218.
}

penelitian ini disejajarkan, disamakan, atau dipadankan.

Selanjutnya, Nida mengklasifikasikan makna berdasarkan dua faktor yang saling menyilang, yaitu kognitif-emotif dan ekstralingual-intralingual. Dua persilangan ini menghasilkan makna referensial (persilangan antara kognitif dan ekstralingual) dan makna gramatikal (persilangan antara kognitif dan intralingual). Nida menyebutkan bahwa makna referensial didasarkan pada relasi satuan leksikal dengan referen, atau biasa disebut denotata (jamak denotatum). Akan tetapi, denotata ini bukanlah makna. Menurutnya, makna adalah himpunan struktur kognitif yang memungkinkan penandaan denotata dengan suatu satuan leksikal. ${ }^{11}$

Dengan kata lain, makna terdiri dari seperangkat fitur konseptual yang memungkinkan penutur dapat memilah dan membedakannya dengan seperangkat fitur konseptual lainnya dalam sebuah medan makna. Sedangkan konteks, menurut Hazim Ali, adalah panggung atau tempat suatu kata pada posisinya. Konteks terdiri dari dua unsur, yaitu unsur bahasa (struktur ungkapan) dan unsur luar bahasa (situasi psikologis, pengetahuan, relasi sosial, dan unsur lain di luar bahasa). ${ }^{12}$

\section{Teori Semiotika}

Saussure dan Pierce sama-sama memandang semiotika sebagai ilmu tanda (Nöth, 1995). Tanda "bahasa" (sign),atau "signifikasi" di dalam semiotika, menurut Saussure (dalam Nöth, 1995), terdiri atas penanda "parole" (signifiant/signifier) dan petanda "langue" (signifie/signified).

11 Ibid., h. 25-29.

12 Hâzim Ali Kamâl al-Dîn, Durûs fî́Ilm alLughah al-Âm (Kairo: Maktabah al-Adab, 1999), h. 121-122. 
Makna sebuah tanda dihasilkan dari hubungan antara penanda dan petanda. Dalam berkomunikasi, pengirim pesan (sender) menggunakan tanda (sign) untuk mengirim makna suatu objek dan penerima (receiver) akan menginterpretasikan tanda tersebut. Objek, bagi Saussure, disebut referent.

Sementara itu, dalam semiotika "komunikasi", Pirece (dalam Nöth, 1995) mengemukakan segitiga makna (triangle meaning) yang terdiri atas sign, object, dan interpretant.Sign (tanda) adalah sesuatu yang dapat ditangkap oleh pancaindra manusia.Signmerupakan sesuatu yang merujuk atau merepresentasikan hal lain di luar diri manusia.

Menurut Pierce,tanda terdiri atas simbol, ikon, dan indeks. Dalam pandangan Pierce, object dianggap sebagai acuan tanda yang berupa konteks sosial dan menjadi referensi dari tanda yang dirujuk. Sedangkan, interpretant atau pengguna tanda adalah konsep pemikiran dari orang yang menggunakan tanda dan menurunkannya ke suatu makna tertentu atau makna yang ada di dalam benak seseorang tentang object yang dirujuk sebuah tanda. ${ }^{13} \mathrm{Hal}$ terpenting di dalam semiotika Pierce adalah bagaimana makna muncul dari sebuah tanda ketika tanda tersebut digunakan orang saat berkomunikasi.

Perbedaan mendasar antara semiotika Saussure dan Pierce terletak pada masalah object. Bagi Saussure, object adalah referent dan merupakan unsur tambahan dalam proses penandaan. Sedangkan, Pierce memasukkan object ke dalam teori segitiga makna. Persamaan atau "kemiripan" antara keduanya dapat dilihat dari istilah yang digunakan Pierce maupun Saussure,

13 Winfried Nöth, Handbook of Semiotic (Bloomington and Indianapolis: Indiana Unversity Press, 1995), cet. I, h. 235. interpretant untuk signifie dan object untuk signifier.

Secara terperinci, Barthes (dalam Nöth, 1995) menjelaskan bahwa sistem signifikasi tanda terdiri atas relasi ( $\mathrm{R}=$ relation) antara tanda (E=expression) dan maknanya $(\mathrm{C}=$ content $)$. Sistem signifikasi tanda tersebut dibagi menjadi sistem pertama (primer) yang disebut sistem denotatif dan sistem kedua (sekunder) yang dibagi lagi menjadi dua, yaitu sistem konotatif dan sistem metabahasa. Di dalam sistem denotatif, terdapat relasi antara tanda dan maknanya, sedangkan dalam sistem konotatif terdapat perluasan atas signifikasi tanda (E) pada sistem denotatif. Sementara itu, di dalam sistem metabahasa terhadap perluasan atas signifikasi makna (C) pada sistem denotatif. Dengan demikian, dapat disimpulkan bahwa sistem konotatif dan sistem metabahasa merupakan perluasan dari sistem denotatif.

Dalam sistem penandaannya, Barthes (dalam Nöth, 1995) menambahkan adanya mitos yang menandai suatu masyarakat. Menurutnya, mitos terletak pada penandaan kedua. ${ }^{14}$ Artinya, setelah terbentuk sistem sign-sigifier-signified, tanda akan menjadi penanda baru yang kemudian memiliki petanda kedua dan membentuk tanda baru. Dengan kata lain, ketika suatu tanda yang memiliki makna konotasi kemudian berkembang menjadi makna denotasi, maka makna denotasi tersebut akan menjadi mitos.

\section{Semiotika al-Qur'an}

Pembacaan semiotik tidak hanya menganalisis tanda-tanda dan mencari tingkatan makna yang ada. Dalam kajian semiotika komunikasi, tanda-tanda tersebut merupakan wahana untuk komunikasi.

\footnotetext{
$14 \quad$ Ibid., h. 267.
} 
Jika pembacaan semiotik ini diterapkan dalam kajian al-Qur'an, maka lahirlah sebuah cabang baru disebut semiotika al-Qur'an. Sebab, al-Qur'an mengandung tanda-tanda bahasa yang memiliki arti kompleks, yang merupakan wahana komunikasi Tuhan dengan manusia. Hal ini berimplikasi pada anggapan bahwa alQur'an (tanda dan bahasanya) dipandang sebagai sesuatu yang profan (tidak sakral). Namun, anggapan seperti ini bukan berarti menafikan sakralitas al-Qur'an dalam arti yang sebenarnya.

Menganggap bahasa Arab-seperti bahasa-bahasa di dunia pada umumnyasebagaisebuah produk budaya yang memiliki sistem tanda adalah sesuatu yang menarik untuk dikaji.Pandangan seperti ini menganggap al-Qur'an,dengan bahasa Arabnya, merupakan sebuah tanda,dan untuk menemukan meaning (arti) dan sense (makna) harus dikaji sistem tanda yang ada di dalamnya. Konsep-konsep yang berada di balik sistem tanda pada bahasa al-Qur'an dicari dengan meneliti pola hubungan antara penanda dan petanda.

Pembacaan terhadap al-Qur'an dilakukan melalui dua tahap, yaitu pembacaan heuristik dan pembacaan retroaktif. Pembacaan heuristik adalah pembacaan berdasarkan konvensi bahasa, atau berdasarkan konvensi sistem semiotik tingkat pertama. Pembacaan retroaktif adalah pembacaan berdasarkan sistem semiotik tingkat kedua, atau berdasarkan konvensi di atas konvensi bahasa. Dua tahapan pembacaan di atas menghasilkan tingkatan makna yang berbeda. Dapat pula dikatakan bahwa pembacaan heuristik adalah pembacaan secara semantik, sedangkan pembacaan retroaktif adalah pembacaan secara hermeneutik.
Perlu ditegaskan di sini bahwa semiotik tidak cukup hanya menganalisis tandatanda dan mencari tingkatan makna yang ada. Artinya, jika dikaji lebih dalam, maka pembacaan secara semiotik juga akan dapat melahirkan makna-makna baru yang berbeda dari makna-mana sebelumnya. Dengan demikian, makna konotasi yang dihasilkan dari pembacaan secara retroaktif juga dapat memunculkan makna konotasi yang lain. Dalam pandangan Barthes (dalam Nöth, 1995), makna konotasi dapat berkembang menjadi makna denotasi, dan seterusnya.

\section{Diskusi Temuan}

Analisis kisah Nabi Yusuf pada dasarnya menganggap kisah tersebut sebagai media komunikasi yang berdiri sendiri dan terlepas dari dunia luar. Analisis ini dilakukan dengan asumsi bahwa kisah Nabi Yusuf merupakan sebuah struktur wacana atau bahasayang dibangun melalui kebahasaan dan struktur naratif yang membangun kisah Nabi Yusuf dalam QS Yûsuf. Berikut ini merupakan hasil analisis yang telah dilakukan oleh Imron (2011) dalam membaca kisah dalam QS Yûsuf.

Pembacaan secara heuristik dan secara retroaktif terhadap al-Qur'an merupakan sebuah keharusan untuk menemukan pesan yang terkandung di dalamnya. Sebagaimana diketahui, Nabi Yusuf tidak secara langsung dikatakan sebagai orang yang tampan. Kesimpulan ini diambil dari hasil pembacaan secara heuristik dan secara retroaktif terhadap kisah Nabi Yusuf yang disampaikan al-Qur'an.

Peristiwa yang menceritakan ketampanan Nabi Yusuf dimulai ketika Nabi Yusuf dewasa. Hal ini terjadi sebagaimana umumnya, bahwa manusia, baik laki-laki maupun perempuan, dianggap menarik 
ketika menginjak usia dewasa. Dalam QS Yûsuf [12] ayat 22 dinyatakan:

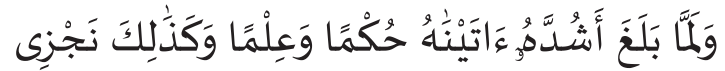

$$
\begin{aligned}
& \text { ألمْحْسِنِينَ }
\end{aligned}
$$

"Dan tatkala dia cukup dewasa, Kami berikan kepadanya hikmah dan ilmu. Demikianlah Kami memberi balasan kepada orang-orang yang berbuat baik."

Penggunaan huruf wawu [9] ("dan") yang ditempatkan di awal kalimat merupakan tanda bahasa yang berfungsi sebagai isti'nâfiyyah atau pembukaan ulang. ${ }^{15}$ Pembentuk kohesi ini berfungsi sebagai penanda atas permulaan babak atau episode baru dari sebuah bangunan peristiwa besar yang utuh. Di sini, Yusuf disebut sebagai seorang pemuda yang matang dan dewasa, serta memiliki ilmu pengetahuan dan hikmah.

Episode baru tersebut dimulai dengan pernyataan mengenai kematangan usia Nabi Yusuf. Kematangan ini ditandai dengan klausa /wa lammâ balagha asyuddahû/. Kata /balagha/berarti 'telah sampai', sedangkan kata /asyudda/ merupakan bentuk plural dari kata /syiddah/ atau /syadd/ yang berarti 'keras'. Keras dalam konteks klausa ini memiliki pengertian keras secara fisik atau tubuh yang kuat. Penggunaan kata tertentu untuk menunjuk makna tertentu seringkali ditemukan pada setiap rangkaian cerita yang ada. Al-Qur'an tidak secara langsung menyebut / bâligh/atau /al-syâb/ yang juga berarti telah masuk usia muda atau dewasa. Pada ayat sebelumnya, Yusuf kecil dinyatakan sebagai /ghulâm/ 'anak muda'. Perhatikan QS Yûsuf [12] ayat 19 berikut ini:

\footnotetext{
15 Bahjat 'Abd al-Wâhid Shâlih al-I'râb alMufashshal li Kitâbillâh al-Murattal (Amman: Dâr alFikr, 1998), h. 274.
}

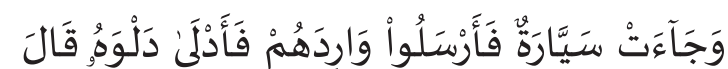

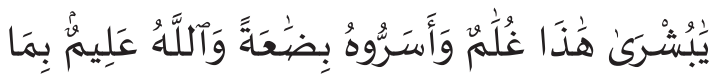

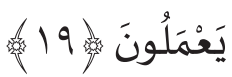

"Kemudian datanglah sekelompok musafir, lalu mereka menyuruh seorang pengambil air. Dia lalu menurunkan timbanya. Dia berkata: 'Oh, kabar gembira, ini seorang anak muda!' Kemudian, mereka menyembunyikan dia sebagai barang dagangan, dan Allah Maha Mengetahui apa yang mereka kerjakan."

Ayat tersebut di atas menerangkan bahwa Yusuf baru ditemukan oleh seorang musafir yang sedang menimba air di sumur. Apabila kedua kalimat dalam ayat di atas dihubungkan (yakni kalimat tentang penemuan Yusuf oleh para musafir dan penyembunyian Yusuf sebagai barang dagangan), maka ada rentang waktu yang tidak dijelaskan dalam cerita. Hal ini menunjukkan bahwa peristiwa-peristiwa di rentang waktu tersebut tidak terlalu penting.

Adapun ketampanan Nabi Yusuf mulai terlihat ketika Yusuf sudah mencapai usia dewasa dengan dianugerahi / $\underline{\mathrm{h} u \mathrm{~km} /}$ 'hikmah' dan /'ilm/ 'ilmu'. Hikmah adalah keilmuan aplikatif yang bermanfaat untuk diterapkan, sedangkan ilmu yang dimaksud adalah ilmu menakwilkan sesuatu (mimpi). ${ }^{16}$ Dalam banyak literatur, usia dewasa Yusuf kala itu, sebagaimana keterangan ayat QS Yûsuf di atas, diperkirakan berusia 30-35 tahun.

Penggalan kisah di atas merupakan prolog sebelum memasuki kisah Nabi Yusuf dengan imra'ah 'azîzah (perempuan mulia/ terhormat). Dalam beberapa penafsiran

16 M. Quraish Shihab, Tafsir Al-Misbah: Pesan, Kesan dan Keserasian Al-Quran, vol. 6 (Jakarta: Lentera Hati, 2002), h. 416. 
QS Yûsuf (12): 21, diterangkan bahwa pertemuan antara imra'ah 'azîzahdan Yusuf terjadi ketika Yusuf masih kecil dan baru dibeli dari pedagang budak. Yusuf kecil lalu diadopsi oleh imra'ah 'azîzahdan suaminya. Dalam beberapa riwayat disebutkan bahwa pilihan mengadopsi Yusuf kecil adalah karena imra'ah 'azîzah dan suaminya (Potifar)-yangmerupakan seorang pejabat tinggi di Mesir-tidakmemiliki anak dan keduanya sangat menginginkan kehadiran seorang anak yang baik dan tampan. ${ }^{17}$

Terdapat dua pertemuan antara imra'ah 'azîzahdan Yusuf yang dikisahkan al-Qur'an. Pertemuan pertama tidak diulas secara panjang lebar. Hal ini dapat diartikan bahwa pertemuan pertamaitu tidak menduduki posisi penting dalam keseluruhan alur cerita al-Qur'an. Namun, hal ini berbeda dengan pertemuan selanjutnya. Pada pertemuan kedua, antara Yusuf dan imra'ah 'azîzah terjadi hubungan konflik yang saling mengecualikan. Konflik tersebut dinyatakan dalam QS Yûsuf [12] ayat 23-24 berikut:

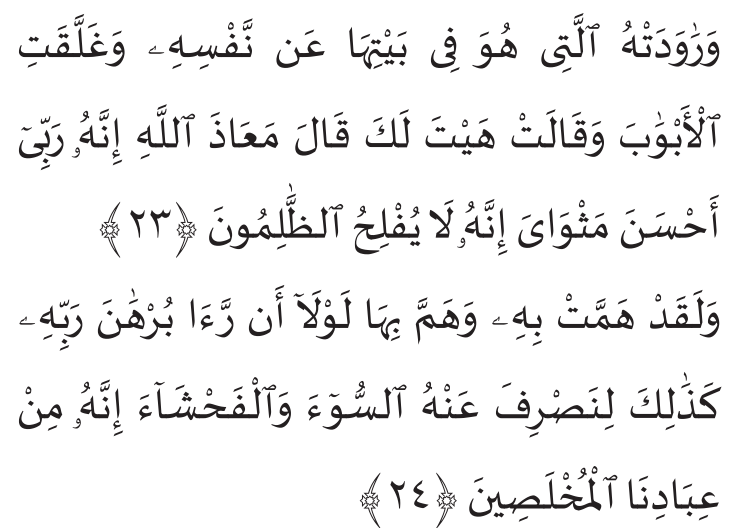

"dan wanita (Zulaikha) yang Yusuf tinggal di rumahnya menggoda Yusuf untuk menundukkan dirinya (kepadanya) dan dia menutup pintupintu seraya berkata: 'Marilah ke sini.' Yusuf berkata: 'Aku berlindung kepada Allah, sungguh tuanku telah memperlakukan aku dengan baik.'

17 Ibid., h. 418.
Sesungguhnya orang-orang yang zalim itu tidak beruntung. Sesungguhnya wanita itu telah berhasrat (melakukan perbuatan itu) dengan Yusuf, dan Yusufpun berhasrat (melakukan pula) dengan wanita itu andaikata Dia tidak melihat tanda (dari) Tuhannya. Demikianlah, agar Kami memalingkan darinya kemungkaran dan kekejian. Sesungguhnya Yusuf itu termasuk hamba-hamba Kami yang terpilih."

Klausa /râwadathu/ 'menggoda untuk menundukkan' menunjukkan pelaku adalah imra'ah 'azîzah, sedangkan objek pelakunya adalahYusuf.Kata/râwada/berasaldarikata /râda/yang berarti upaya meminta sesuatu dengan lemah lembut agar yang diharapkan dapat diperoleh. ${ }^{18}$ Dalam kejadian ini, pelakunya adalah seorang perempuan dewasa, sedangkan objeknya adalah lakilaki dewasa yang baru saja sampai pada usia kematangan. Hal ini menunjukkan bahwa upaya tersebut berwujud rayuan atau godaan. Hal ini juga diperkuat dengan frasa /'an nafsihî/ yang mengacu pada klausa di atas sehingga memiliki arti untuk menundukkan Yusuf. ${ }^{19}$

Ketertarikan dan rasa cinta imra'ah 'azîzah terhadap Yusuf disebabkan karena mereka berdua tinggal dalam satu rumah, dan Yusuf telah sampai pada masa-masa perkembangan diri sebagai seorang lakilaki yang sempurna. Sementara itu, imra'ah 'azîzahjuga selalu memperhatikan dan mengamati perkembangan Yusuf sejak/ gulâm/ 'pubertas' sampai /asyuddah/ 'dewasa'. Selain itu, imra'ah 'azîzah adalah wanita yang telah lama tidak berhubungan intim karena suaminya lemah syahwat. Sebagai wanita normal, imra'ah 'azîzah tentu ingin melampiaskannya dengan

18 Ibid., h. 425.

19 Bahjat 'Abd al-Wâhid Shâlih op o cit., h. 287. 
Yusuf yang rupawan, apalagi imra'ah 'azîzahadalah termasuk wanita yang belum memiliki keimanan dan ketakwaan yang kuat sehingga setan sangat mudah untuk menggoda nafsu syahwatnya. ${ }^{20}$ Usaha untuk menundukkan Yusuf telihat pada klausa / wa ghallaqat al-abwâb/dan /wa qâlat haita laka/.

Usaha untuk menundukkan Yusuf tidak hanya rayuan verbal, tetapi juga dengan tindakan, yakni menutup pintu, mengecek dan memastikan semua celah telah terkunci rapat. Penggunaan kata /ghallaqat/ yang berasal dari kata ghalaqa(menutup) mununjukkan aktivitas yang dilakukan berulang-ulang, yaitu menutup pintu secara berulang-ulang, menutup rapat, menutup semua celah, dan mengecek kembali apakah semua celah/pintu benarbenar tertutup. Untuk itu, digunakanlah kata dalam bentuk plural /abwâb/ 'pintupintu'. Apa yang dilakukan oleh imra'ah 'azîzahdengan menutup semua pintu adalah usaha untuk mengirimkan pesan birahi kepada Yusuf.

Komunikasi semakin jelas setelah imra'ah 'azîzah mengucapkan /haita laka/. Kata /haita/ memiliki arti 'marilah kemari', sedangkan kata /laka/ bertujuan menegaskan bahwa ajakan tersebut diperuntukkan buat lawan bicaranya, yaitu Yusuf. Penyebutan hanya pada kedua tokoh tersebut menunjukkan rumah itu dalam keadaan sepi atau hanya mereka berdua saja. Dengan demikian, ungkapanungkapan tersebut merupakan bentuk ekspresi dorongan birahi imra'ah 'azîzah yang telah terpesona oleh ketampanan Yusuf.

Dalam Perjanjian Lama, peristiwa tersebut dinyatakan dengan cerita yang

20 Ayatullah al-Uzma Nasir Syirazi, QashashalQur'ân (Iran: Mu'assasah Ansariyah, 2005), h. 125. lebih vulgar sebagai berikut: Selang beberapa waktu, istri tuannya memandang Yusuf dengan birahi, lalu katanya, "Marilah tidur dengan aku" (7). Walaupun dari hari ke hari perempuan itu membujuk Yusuf, Yusuf tidak mendengarkan bujukannya itu untuk tidur di sisinya dan bersetubuh dengan dia (10). (Kitab Kejadian 39: 7 dan 10)

Klausa /laqad hammat bihî/ yang mengacu pada hasrat seksual imra'ah 'azîzahmerupakanbuktiyangmenunjukkan hal tersebut.Hal ini diperkuat dengan penggunaan preposisi /la/ dan /qad/ menjadi /laqad/ 'sungguh atau benarbenar' sebelum verba, sehingga klausa tersebutbisa diartikan'sungguh perempuan itu benar-benar sangat ingin melakukan dengan Yusuf'. Sebaliknya, klausa /wa hamma bihâ / 'Yusuf ingin melakukan juga dengan dia'mengacu pada diri Yusuf.

Dua klausa di atas tampaknya hampir sama, akan tetapi keduanya memiliki perbedaan. Perbedaan keduanya disebabkan ada klausa /law lâ an ra'â burhâna rabbihi/ 'jika tidak melihat kebesaran Tuhannya' yang mengikuti klausa /wa hamma bihâ/. Ungkapan tersebut, di satu sisi, menggambarkan aspek manusiawi Yusuf yang memiliki kebutuhan biologis, tetapi di sisi lain,menegaskan juga aspek kesadaran tentang kebesaran Tuhan yang tumbuh kuat di dalam pribadi Yusuf. Dan, kesadaran tentang Allah inilah yang mampu mengendalikan hasrat seksualnya.

Kesadaran terhadap kebesaran Allah Swt mendorong Yusuf untuk berpaling dari imra'ah 'azîzahsehingga terjadi peristiwa berikutnya, yaitu keduanya berlomba-lomba menuju pintu, sebagaimana dijelaskan dalam klausa /istabaqâ al-bâb/ (QS Yusuf [12]: 25). 


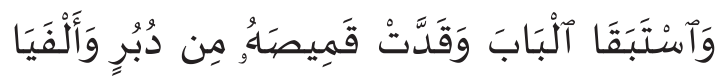

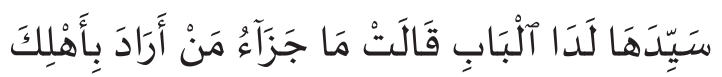

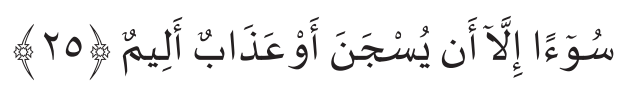

Dan keduanya berlomba-lomba menuju pintu, dan wanita itu menarik baju gamis Yusuf dari belakang hingga koyak. Keduanya mendapati suami wanita itu di muka pintu. Wanita itu berkata: "Apakah pembalasan terhadap orang yang bermaksud berbuat serong dengan istrimu, selain dipenjarakan atau (dihukum) dengan azab yang pedih?"

Klausa /istabaqâ al-bâb/ 'mereka berdua berlomba-lomba menuju satu pintu' menunjukkan mereka berdua berlari menuju pintu yang sama, dengan Yusuf dalam posisi di depan. Hal ini ditunjukkan oleh klausa /qaddat qamîshahu min dubur/ 'wanita itu menarik baju Yusuf dari belakang'. Setelah keduanya sampai di pintu yang dituju, muncullah tokoh al-'Azîz (Suami imra'ah 'azîzah) sebagai penetral antara Yusuf dan imra'ah 'azîzah. Dengan adanya tokoh baru ini, alur ceritanya menjadi turun dan berganti peristiwa.

Peristiwa-peristiwa selanjutnya tidak terlalu menonjolkan sisi ketampanan Nabi Yusuf, baik secara fisik maupun psikis. Peristiwa-peristiwa ini lebih pada pembelaan Yusuf atas tuduhan yang dilontarkan oleh imra'ah 'azîzah yang mengadu kepada suaminya dengan pernyataan: "Apakah pembalasan terhadap orang yang ingin berbuat serong /sû'/ dengan istrimu selain dipenjarakan atau dihukum dengan azab yang pedih". Yusuf pun membela dirinya dengan menyatakan "Dia menggodaku untuk menundukkan diriku" (ayat 26). Al-'Azîz menangkap baik dua pesan tersebut sehingga dia pun bersikap netral. Dia kemudian mempersilahkan saksi untuk menyelesaikan konflik antara Yusuf danimra'ah 'azîzah. Peristiwa ini direkam baik dan dinyatakan pada ayat-ayat selanjutnya (ayat 26-29).

Selanjutnya, peristiwa yang menunjukkan ketampanan dan kerupawanan Nabi Yusuf digambarkan sangat baik melalui QS Yûsuf [12] ayat 30:

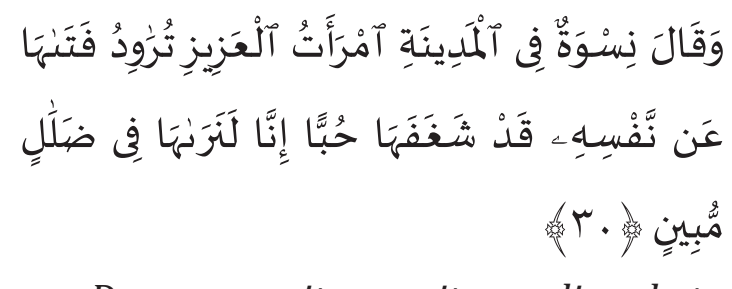

Dan wanita-wanita di kota berkata: "Istri al-Azîz menggoda bujangnya untuk menundukkan dirinya (kepadanya). Sesungguhnya cintanya kepada bujangnya itu sangat mendalam. Sungguh, kami memandangnya dalam kesesatan yang nyata."

Kata /niswah/ pada klausa /qâla niswatun fí al-madînah/ 'wanita-wanita Mesir'. Kata /niswah/ bersinonimi dengan kata /nisâ'/ 'wanita'. Keduanya sama-sama bermakna plural. Perbedaannya adalah kata /niswah/ berarti plural dengan jumlah sedikit, sedangkan nisấ berarti plural dengan jumlah banyak. ${ }^{21}$ Untuk itu, kata / niswah/ di atas menunjukkan arti wanitawanita tertentu di kota Mesir. Dan, pada umumnya, seorang istri pejabat lebih suka bergaul dengan istri-istri pejabat lainnya.

Setelah kabar skandal seks itu terdengar, wanita-wanita tersebut menggunjing imra'ah 'azîzahdengan mengatakan / imra'ah al-'azîz turâwidu fatâhâ, qad syagafahâhubban, innâ lanarâhâ fî dhalalin mubîn/ 'Isteri al-'Aziz menggoda bujangnya untuk menundukkan dirinya (kepadanya). Sungguh, cintanya kepada bujangnya itu adalah sangat mendalam'. Kata / $\underline{\text { ubban/ }}$

\footnotetext{
21 Bahjat 'Abd al-Wâhid Shâlih, op. cit., h. 290.
} 
pada klausa /qad syaghafahâhubban/ berarti 'cintayang meluap-luap', ${ }^{22}$ sedangkan

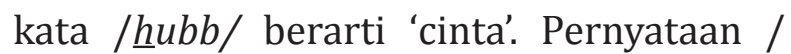
syaghafahâhubban/ memiliki makna cinta yang sangat khusus, dalam konteks ini, cinta yang lebih. Cinta ini adalah puncak dari rasa cinta yang dimiliki seseorang sehingga cenderung ingin menguasai orang yang dicintainya.

Setelah imra'ah 'azîzah mendengar gunjingan yang dialamatkan kepada dirinya, wanita-wanita itu pun diundang dalam sebuah perjamuan. Alasan imra'ah 'azîzahmengundang wanita-wanita istri pejabatMesir itu adalah ingin membuktikan bahwa apa yang dituduhkannya tidaklah benar. Pernyataan ini dinyatakan dalam QS Yûsuf [12] ayat 31:

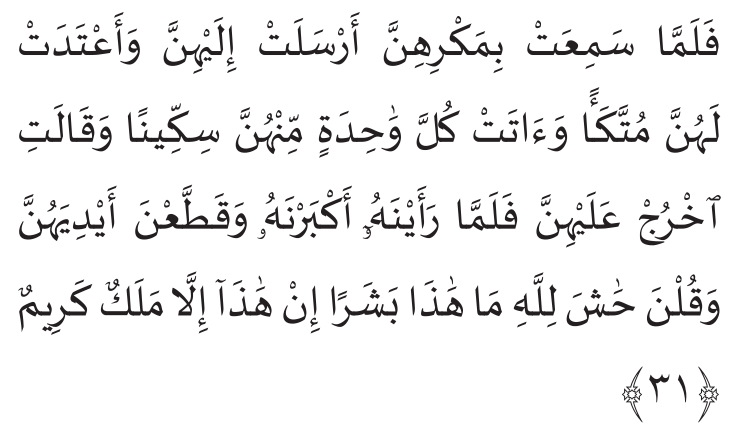

Tatkala wanita itu (Zulaikha) mendengar cercaan mereka (wanitawanita di kota), maka mereka diundang (ke rumahnya) dan disediakan tempat duduk bagi mereka, lalu diberikan kepada masing-masing mereka sebuah pisau (untuk memotong jamuan), kemudian dia berkata (kepada Yusuf): "Keluarlah (tampakkanlah dirimu) kepada mereka." Maka, tatkala wanitawanita itu melihatnya, mereka kagum kepada (keelokan rupa)-nya, dan mereka melukai (jari) tangannya. Mereka berkata: "Mahasempurna Allah!Ini bukanlah manusia. Sungguh, ini tiada lain malaikat yang mulia."

22 M. Quraish Shihab, op. cit., h. 440.
Kata /makrihinna/ berarti 'tipu daya', namun setelah dihubungkan dengan kata ganti ketiga /hunna/ (kata ganti plural wanita) dan dihubungkan dengan peristiwa pada ayat QS Yusuf (12): 30, maka kata / makrihinna/ berarti fitnah yang mengacu pada perkataan buruk wanita-wanita Mesir. Untuk itu, mereka diundang dalam sebuah perjamuan. Setelah wanita-wanita Mesir menghadiri perjamuan imra'ah 'azîzah, Yusuf dipanggil untuk menampakkan dirinya kepada wanita-wanita tersebut.

Klausa /qâlat ukhruj 'alaihinna/ berarti perintah kepada Yusuf untuk keluar sekadar menampakkan diri. Setelah mereka melihat Yusuf, mereka pun kagum terhadap keelokandan ketampanan rupaYusuf, dan mereka melukai (jari) tangannya. Mereka berkata: "Mahasempurna Allah! Ini bukanlah manusia. Sungguh, ini tiada lain malaikat yang mulia." Klausa / akbarnahû/ memiliki arti kekaguman terhadap ketampanan atau keelokan Yusuf, sedangkan kata /qaththa'na/dalam klausa / qaththa'na aidiyahunna/berarti memotong berulang-ulang jari tangan mereka. Klausa ini jika dihubungkan dengan pesona Yusuf, maka berarti: wanita-wanita Mesir itu tidak menyadari telah memotong jari tangan mereka sendiri secara berulang akibat terpesona oleh ketampananYusuf.

Setelah imra'ah 'azîzah merasakan bahwa pesan yang dia kirim telah diterima oleh wanita-wanita Mesir tersebut, dia mengatakan: 'Itulah yang kamu cela terhadapku karena aku tertarik kepadanya'. Imra'ah 'azîzah kemudian mengakui bahwa dirinya telah merayu dan menggoda Yusuf agar takluk dipelukannya, tetapi Yusuf menolak rayuannya. Imra'ah 'azîzah sendiri menganggap bahwa ketertarikannya pada Yusuf adalah hal yang wajar. Sebab, ketertarikan itu juga dirasakan 
oleh wanita-wanita Mesir itu. Imra'ah 'azîzahjuga menyatakan: Jika menolak ajakan dan perintahnya, niscaya Yusuf akan dipenjarakan dan dia termasuk golongan orang-orang yang hina, sebagaimana dijelaskan dalam QS Yûsuf [12]: 32.

Dua peristiwa kekaguman imra'ah 'azîzah dan wanita-wanita Mesir terhadap Yusuf pada dasarnya adalah rangkaian peristiwa yang menunjukkan bahwa Nabi Yusuf adalah seorang manusia yang sangat tampan dan rupawan secara keseluruhan, baik fisik maupun psikisnya. Peristiwa di atas juga menggambarkan betapa Yusuf sosok manusia suci dengan budi pekerti yang bijaksana. Pesan-pesan tersebut disampaikan oleh Allah Swt. secara tidak langsung tetapi melalui sebuah kisah naratif tentang peristiwa kehidupan Nabi Yusuf.

\section{Simpulan}

Penelitian ini merupakan penelitian linguistik terapan terhadap al-Qur'an dengan pendekatan semiotika al-Qur'an. Sebagaimana diketahui, linguistik mengkaji bahasasebagaisebuahsistemlambangbunyi. Sedangkan, al-Qur'an menggunakan bahasa Arab sebagai media untuk menyampaikan pesan-pesan Ilahi kepada manusia. Ditinjau dari semiotik, bahasa merupakan tandatanda yang dapat dimaknai secara objektif sesuai dengan kaidah atau sistem bahasa "Arab" yang berlaku secara umum. Proses penandaan atau pemaknaan yang paling sederhana adalah melalui pemaknaan secara semantik. Dalam penelitian ini,proses pemaknaan terhadap ayat-ayat al-Qur'an dilakukan secara semantik dan secara semiotik.

Apayang disampaikanal-Qur'an melalui kisah ketampanan Nabi Yusuf ini telah banyak melahirkan sebuah presuposisi (praanggapan) yang dimaksudkan oleh pengirim pesan. Melalui jalinan peristiwa yang dituturkan atau diceritakan dengan bahasa yang terstruktur, pengirim pesan telah mengantisipasi pemahaman pembaca terhadap isi pesan tersebut. Secara naratif, penggalan kisah tentang ketampanan $\mathrm{Nabi}$ Yusuf tidak hanya memuat rangkaian peristiwa tanpa makna, tetapi mengandung pesan-pesan dan makna tertentu yang berhubungan dengan perintah-perintah agama, seperti perintah untuk menjaga diri dari perbuatan zina, sebagaimana ditunjukkan oleh pribadi Yusuf yang memiliki kesadaran takwa kepada Allah.

Pesan-pesan tersebut telah dirangkai oleh al-Qur'an dalam bentuk peristiwa, dan untuk memahami isi pesannya, diperlukan pemahaman kebahasaan yang baik untuk memahami teks atau ayat-ayat yang menceritakan Nabi Yusuf. Dengan mengetahui keutuhan teks itu, baik kohesi maupun koherensinya, maka akan lebih mudah memahami isi wacana yang dibangun oleh teks tersebut. Pada akhirnya, peneliti menemukan bahwa jalinan makna yang dimaksud oleh pengirim pesan tentang ketampanan Nabi Yusuf adalah idealitas kepribadian yang layak dicontoh oleh insan bertakwa. []

\section{Daftar Rujukan}

Arkoun, Mohammed, Nalar Islami dan Nalar Modern: Berbagai Tantangan dan Jalan Baru. Jakarta: INIS, 1994.

\section{Berbagai Pembacaan Al-Quran.}

Jakarta: INIS, 1997.

Cresswell, John W.,Research Design:

Qualitative, Quantitative, and Mixed Methods Approaches, Third Edition, USA: Sage Publication, Inc., 2009. 
Cruse, D. Alan, Lexical Sementics, Cambridge: Cambridge University Press, 1986.

Meaning in Language: An Introduction to Semantics andPragmatics, Oxford: Oxford University Press, 2004.

Imron, Ali, Semiotika Al-Quran: Metode dan Aplikasi Terhadap Kisah Yusuf, Yogyakarta: Teras, 2011.

Kamâl al-Dîn, ㅂâzim Ali,Durûs fi 'Ilm al-Lughah al-Âm, Kairo: Maktabah a-Adab, 1999.

Lyons, Jhon, Semantic, Cambridge: Cambridge University Press, 1977.

LinguisticSemantics: An Introduction. Cambridge: Cambridge University Press, 1995.

Nida, Eugene A,Componential Analysis of Meaning: An Introduction of Semantic Structure, The Hague: The Netherlands Mouton \& Co. NV. Publisher, 1975.

Nöth, Winfried,Handbook of Semiotic. Bloomington and Indianapolis: Indiana Unversity Press, 1995.

Shâlihh, Bahjat 'Abd al-Wâhid, al-I'râb al-Mufashshal li Kitâbillâh al-Murattal, Amman: Dâr alFikr, 1998.

Shihab, M. Quraish, Tafsir Al-Misbah: Pesan, Kesan dan Keserasian al-Quran, Vol. 6. Jakarta: Lentera Hati, 2002.

Syirazi, Ayatullah al-Uzma Nasir, Qashas al-Qur'ân, Iran: Mu’assasah Ansariyah, 2005. 
Arabiyât Jurnal Pendidikan Bahasa Arab dan Kebahasaaraban 